\title{
Influence of a seed capital program for supporting high growth firms in Chile
}

\author{
Influencia de un programa de capital semilla para apoyar a empresas \\ de alto crecimiento en Chile
}

\author{
Christian A. Cancino*, Alicia Núñez, José M. Merigó \\ Universidad de Chile, Chile
}

Received November 29, 2017; accepted November 5, 2018

Available online November 23, 2018

\begin{abstract}
The main economic development agency in Chile, CORFO, implemented in 2001 a Seed Capital Program (SCP) to promote the development of high-growth firms. The SCP not only provides financial aid to entrepreneurs but also technical and administrative assistance through the support of incubators. Incubators may be universities incubators (UI) or private firms (NUI). The aim of this paper is to know the performance of beneficiaries according to the assistance of UI or NUI. A total of 238 new firms beneficiaries with the CORFO program were surveyed ( 84 supported by UI and 154 supported by NUI). Two logistic regression models were used, a first model to assess the probability that a new firm achieves positive sales, and a second model to assess the probability that the new firm reaches a high growth during the first five years from its inception. Overall, mixed results were found. SCP's beneficiaries supported by either UI and NUI have the same probability of having positive sales when starting their operations.
\end{abstract}

*Corresponding author.

E-mail address: cancino@fen.uchile.cl (C.A. Cancino)

Peer Review under the responsibility of Universidad Nacional Autónoma de México.

http://dx.doi.org/10.22201/fca.24488410e.2019.1810

0186- 1042/@ 2019 Universidad Nacional Autónoma de México, Facultad de Contaduría y Administración. This is an open access article under the CC BY-NC-SA (https://creativecommons.org/licenses/by-nc-sa/4.0/) 
However, five years after started their operations, businesses supported by UI have higher probabilities of achieving high growth than businesses supported by NUI. The results highlight a positive interaction between private entrepreneurs, public agencies and university incubators.

JEL Codes: M13, L25 L32, L38

Keywords: High-growth, Seed Capital, Evaluation, University incubators.

\section{Resumen}

La principal agencia de desarrollo económico de Chile, CORFO, implementó en 2001 un Programa de Capital Semilla (PCS) para promover el desarrollo de empresas de alto crecimiento. El PCS no solo proporciona ayuda financiera a los empresarios, sino también asistencia técnica y administrativa a través del apoyo de las incubadoras. Las incubadoras pueden ser incubadoras de universidades (IU) o empresas privadas (NIU). El objetivo de este documento es conocer el desempeño de los beneficiarios de acuerdo con la asistencia de IU o NIU. Se encuestó a un total de 238 nuevas empresas beneficiarias con el programa CORFO (84 apoyadas por IU y 154 apoyadas por NIU). Se utilizaron dos modelos de regresión logística. Un primer modelo para evaluar la probabilidad de que una nueva empresa logre ventas positivas. Un segundo modelo para evaluar la probabilidad de que la nueva empresa alcance un alto crecimiento durante los primeros cinco años desde su inicio. En general, se encontraron resultados mixtos. Los beneficiarios del PCS respaldados por IU y NIU tienen la misma probabilidad de tener ventas positivas al iniciar sus operaciones. Sin embargo, cinco años después de comenzar sus operaciones, las empresas respaldadas por IU tienen mayores probabilidades de lograr un alto crecimiento que las empresas respaldadas por NIU. Los resultados resaltan una interacción positiva entre empresarios privados, agencias públicas e incubadoras universitarias.

Códigos JEL: M13, L25 L32, L38

Palabras clave: Alto Crecimiento, Capital Semilla, Evaluación, Incubadoras Universitarias.

\section{Introduction}

To foster the development of entrepreneurship, support of the public sector is essential to identify and leverage high impact results and reduce the impact of important issues affecting the entrepreneurial activity. One issue is the difficulty to obtain new financial resources for growing due to the asymmetries faced by private investors to judge the quality and estimate the value of the business ideas (Fairchild, 2011; Audretsch, 2012). Another important issue is the lack of administrative and managerial skills of entrepreneurs hindering the growth of their businesses (Cancino et al., 2015).

Responding to the challenges of project valuation and administration, and hence support a greater number of entrepreneurships, CORFO (Production Development Corporation) introduced in 2001 a Seed Capital Program (SCP) aiming to reduce funding problems, and to guide the entrepreneurs in the foundation and start up of high-growth potential businesses in Chile. According to Kantis and Díaz (2008), a high-growth entrepreneurship is defined as one that is born as a micro business, but grows rapidly into a Small and Medium Enterprise (SME) during its first five years of existence. CORFO's SCP selects business ideas with high growth potential, and supports the entrepreneurs with a non-reimbursable subsidy (from US\$13.000 to US\$86.000 per business idea), to provide not only cash flows, but also technical and 
administrative aid. The technical and administrative support is indirectly facilitated by CORFO through business incubators, which either reside in universities (University Incubators, UI), or are private firms assisting business incubation and startups (Non-Universities Incubators, NUI). Both, UI and NUI receive the funds from CORFO associated to the entrepreneurs benefited with the SCP and provide technical and administrative support, regardless of the entrepreneurs' results. It has been registered that incubators tend to submit projects to the $\mathrm{SCP}$, not all of which are necessarily business ideas with high growth potential. The incentive scheme for the incubators that receive their own income based on the number of projects funded by CORFO may distort the results if their purpose is to maximize their own income, rather than the results of the entrepreneurship. Then our motivation is to test if differences to select projects to be funded by the SCP can be found between both schemes:

\section{Scheme 1: Entrepreneurs, Public Agency (CORFO) and University Incubators (UI)}

Scheme 2: Entrepreneurs, Public Agency (CORFO) and Private Incubators (NUI).

In order to contrast the outcomes of the implementation of SCP with the participation of UI and NUI, two models of logistic regression were applied. The analysis of the results for both models suggests interesting findings. The first model identified no differences regarding the support from UI versus NUI in terms of the probability of initiating sales by a new company. In other words, the scheme 1 is neither better nor worse than scheme 2 at predicting the probability that a business supported by CORFO's SCP will start up. The second logistic model suggests interesting results ascribing scheme 1, indicating that the entrepreneurs that received CORFO's SCP through UI presented a higher probability of growing rapidly than scheme 2, selling US $\$ 100.000$ or more annually before the fifth year since the company foundation. This could be interpreted in the way that UI would support or choose entrepreneurs better than NUI. The agency problems that CORFO has with incubators would be much more significant regarding NUI, compared to UI. The results from the logistic regression models may provide evidence in support the thesis in which the collaboration of the three actors university-government-industry creates a virtuous circle.

\section{Literature review and hyphoteses}

In recent years the scientific literature has been quite extensive on topics such as the growth of new and small companies, program for supporting their innovation activities and the promotion of production through public programs (Cumming, 2007; Collewaert et al., 2010; Norrman and Bager-Sjögren, 2010; Cancino, 2014; Román et al., 2017; Cancino et al., 2018). This is how the studies on innovation and entrepreneurship grow and grow over time (Cancino et al., 2017 a,b; Cancino \& Coronado, 2014).

For example Cumming (2007) analyzes 280 Australian venture capital funds and their investments on 845 new ventures (period 1982-2005). The data analyzed show that the program facilitated investment in new companies, particularly in the early stages and that could be classified as high technology, as well as the provision of monitoring and value added advice to the participating companies. Likewise, Collewaert et al. (2010), in a study for Belgium, evaluated whether public intervention through a program of subsidies of angel networks improves economic growth in the Flanders region. The results show that, first, business angels' 
networks reduce information and financing problems for enterprising companies. Second, there are positive indicators of future potential in terms of the ability to raise and raise new funds, provided they are technology-intensive companies (Cancino \& Bonilla, 2011).

On the other hand, Norrman and Bager-Sjögren (2010) studied a program of the Swedish Innovation Center (SIC) that provided support to innovators in their early stages of development through the delivery of financial capital, advice and networks. The period of this study was between 1994 and 2003. The results indicate that the impact of the support to undertakings in the early stages given by the public program of the SIC is weak or non-existent. The focus of the program was not necessarily on innovative or high-tech companies. Other studies on applied programs in developed economies show mixed results in terms of the success of public intervention to encourage a greater number of ventures (Luukkonen, Deschryvere and Bertoni, 2013, Munari and Toschi, 2014).

According to Bonilla and Cancino (2011), in the case of Latin America, several studies have been developed that analyze the results of public productive support programs.

For instance, Álvarez and Crespi (2000) analyzed a program for promoting the export development of Chilean firms. Analyzing the results of companies supported by the program in the nineties, they found a positive effect on the technological innovation of the exported products and in particular on the number of agreements reached by the companies that go through the Program. They also found that the program does not seem to have significant results in terms of quantitative increases in the types of products exported.

Benavente and Crespi (2003) studied the impact on companies that participated in a program that provides strategic partnerships for small businesses in Chile (PROFO). The results indicate that PROFO has a positive impact on intermediate results (planning, marketing strategies, training), but they have a minor impact on the total productivity of the factors.

In a study for Mexico, Tan and López-Acevedo (2005) analyzed the impact of the program CIMO (Center for International Mobility) and focused on the training and training of workers of different size companies. small and medium. The authors observed a positive impact for the first cohort 1991 - 1993 on the intermediate results, compared to the control group, with respect to investment for training and also for the adoption of quality control processes the companies that received the treatment. In contrast, mixed results were obtained for the second cohort 1993 - 1995 (Bonilla \& Cancino, 2011).

In all the above-mentioned programs, the participation of public productive support agencies can be observed, supporting private entrepreneurs so that their businesses can grow, develop a greater number of innovations or participate in international markets. Normally, the relationship between public agencies and private entrepreneurs is not direct. Public agencies provide financial, administrative or technical assistance through third parties, generally known as business incubators, which can be defined as private firms that seek to benefit from public programs by attracting and supporting entrepreneurs with high growth potential (Díaz de León $\&$ Cancino, 2014). Generally, a good public program design should generate an adequate contract between the interests of business incubators and the growing results of entrepreneurs supported by public programs. The objective of a program should be for companies to grow, and not just increase the number of beneficiaries. A bad design, on the other hand, could generate an opportunistic model for business incubators, where the objective would be to attract as many beneficiaries of the programs as possible. Finally, for the business incubators, it would not matter the real quality or growth opportunity of each beneficiary, but only to support the 
maximum possible of them. So capture the highest possible fee for serving and supporting new entrepreneurs.

Seeing the potential problem of agency that occurs between business incubators and the interests of public programs of productive support, is that many public agencies have developed programs where incubators are not only private firms, but are incubators belonging to universities. The participation of university incubators seeks to eliminate the agency problem mentioned above, since protecting the brand and reputation of the universities could limit the opportunistic behavior of those university business incubators that must be aligned with the objectives of public agencies.

This new relationship of private entrepreneurs, public productive support agencies and university incubators, could be a form or scheme of triple helix type relationship, where the performance of the three actors, could be much more advantageous than the relationship of private with public agencies. It will be interesting to know some definitions of a triple helix scheme to know the potential effects of this type of relationship.

According to Etzkowitz (2007), a model that could be effective in promoting the creation and dissemination of knowledge to promote the development and growth of new businesses is the triple helix model. The thesis of this model is that the potential for innovation and economic development in a knowledge society lies in a more prominent role for the university and in the hybridization of elements from university, industry and government to generate new institutional and social formats for the production, transfer and application of knowledge. This vision encompasses not only the creative destruction that appears as a natural innovation dynamics, but also the creative renewal that arises within each of the three institutional spheres of university, industry and government, as well as at their intersections (Ranga \& Etzkowitz, 2013).

The recognition of universities as producers of knowledge and as a key factor in the innovation systems is addressed by many authors (Etzkowitz \& Ranga, 2010; Rodrigues \& Melo, 2012), posing a clear evolution in their role; firstly seen as an 'ivory tower', concentrating only on its traditional research and teaching tasks, apart from a rather social role or relevant participation in regional economy than an agent of change, generator of knowledge and engine for innovation systems, surpassing the industry as primary resource of economic and social development to the long term.

Despite most of the literature showing studies conducted in the behavior of innovation systems and triple helix applications and the role of university with an entrepreneurial focus in developed countries (Almeida, 2008; Guerrero et al., 2014; Etzkowitz et al., 2005; Rodrigues \& Melo, 2012), there is a body of literature on applications of the triple helix model in developing countries. Authors like Charles (2003), Bernasconi (2005), Saad and Zawdie (2011) and Tiffin and Kunc (2011), address the relevance of the role of the university as a source of knowledge and driving innovative initiatives with potential towards economic growth and regional innovation systems in developing countries.

\section{CORFO in Chile and a potential triple helix scheme}

The national innovation systems phenomenon drives governments from developing countries to create policies that encourage the development of alliances among three spheres. In Chile, the development of a hybrid triple helix scheme trying to encourage the development of new high-growth businesses is observed. The Chilean government, through the Seed 
Capital Program (SCP) of CORFO seeks to provide financial assistance to entrepreneurs with innovative ideas and want to grow, besides helping them with the delivery of technical and administrative assistance through business incubators, many of which are universities that support with knowledge and skills to new businesses.

CORFO's SCP was created in 2001 with the objective of promoting the appearance of new entrepreneurship through the allocation of funding for innovative business projects in Chile. Currently, the SCP has two lines of action: Line 1 and Line 2. Line 1, named Seed Capital for pre-investment studies, is a subsidy to support definition and formulation of innovative business projects. Line 2, called Seed Capital supporting implementation, is a subsidy that allocates resources for launching and implementation of innovative projects with high growth expectations.

CORFO finances up to $90 \%$ of the amount required for the execution of a project in Line 2 , with a maximum of US\$80.000.-, non-reimbursable. This subsidy also finances activities for: industrial and intellectual property protection; market analysis; business plan updates; specialized assistance in the fields of marketing and strategy; among others. In addition, it also funds changes of infrastructure, property leasing, commercial packaging of products including packaging design, manufacture of user's manuals, product certification, brand design, sample production, etc. In order to participate in SCP each entrepreneur must have a counterpart, which can be an intermediary, a business incubator, or any organization enrolled in CORFO and able to provide intellectual capital, i.e. technical and administrative support. Business incubators are typically universities (UI) or private consulting firms registered in CORFO (NUI). The SCP includes a mandatory fee that the entrepreneur must pay to the incubator equivalent to US $\$ 1,000$ per month, with a limit of US\$12,000 per year. The main objective of an incubator, both UI and NUI, is to support entrepreneurs during the creation, implementation and development of their firms, providing timely means to increase their chance of success.

\section{Hypothesis}

The above situation, where entrepreneurs can be supported by both UI and by NUI, brings an interesting question, especially if we want to test the value of the triple helix model in a developing country. Entrepreneurs assisted by UI can have better results than those supported by NUI? In order to try to answer this question, let us study the case of SCP of CORFO and its relationship with incubators through the agency theory ${ }^{1}$.

It would be possible to think that the NUI, being also private, seek to maximize their own objectives rather than those who want to maximize CORFO, so instead of working hard to find, select and empower entrepreneurs with the best business ideas, try maximize the number of entrepreneurs who support, earning a fixed salary for each assisted entrepreneur, rather than promote only the best ideas. Meanwhile, the UI, which do not necessarily seek more financial income from CORFO, but gaining prestige and developing good business case to improve its competitive position as a university, might be more aligned to meet the objectives of CORFO'

\footnotetext{
${ }^{1}$ According to Jensen and Meckling (1976), an agency relationship is a contract under which one person (the principal) engages another person (the agent) to perform a service on their behalf, which involves delegating some decision-making authority to the agent. If both parties in the relationship are utility maximizers, there is good reason to believe that the agent will not always act in the best interests of the principal. Due to the non-existence of adequate control by the principal-agent over the agent, or establishing clear initiatives, which ensure major congruence of objectives, naturally the agents want to maximize their own profits, over the principal-agents'.
} 
SCP, showing fewer problems agency. One could expect based on the triple helix and agency problems literature that the relationship between CORFO (government), the entrepreneur (private) and UI (university) would be richer than the relationship between CORFO, an entrepreneur and a NUI. So our hypotheses are:

H1: Participation of UI in CORFO's SCP, instead of NUI, increases the probability that entrepreneurs generate sales.

H2: Participation of university incubators in SCP, instead of NUI, increases the probability of high growth entrepreneurships.

\section{Data and research method}

The data from this study is drawn from a CORFO database of the SCP Line 1 and Line 2. The dataset includes a sample of 238 firms beneficiaries of CORFO's SCP between 2001 and 2007. The dataset provides contact information for these firms, which were contacted by phone, e-mail or in person to fill out a survey (see appendix 1). Out of the 238 firms who received the SCP subsidy, only 136 remain in place today, with permanent sales and good financial results, even though there is a wide variability in terms of growth level. From the remaining 102 benefited firms commercial operations or tax payments are unknown, and it is clear that sales were never accomplished.

Using this data, the research method considers two logistic or logit regression models to test the defined hypotheses and to study the factors associated with the success of an entrepreneur.

The logit model that we will further develop takes its name from the logistic distribution function. Its concrete form is as follows:

$$
F_{i}=F\left(X_{i}, b\right)=1 / 1+e^{-X_{i} b}=e^{X_{i} b} / 1+e^{X_{i} b}
$$

where $\mathrm{X}$ is the matrix that contains the independent variables and $\mathrm{b}$ is the parameter vector to be estimates. We will use the maximum likelihood method for estimation, as is typical in these cases (Davidson \& Mackinon, 1992). The likelihood function to be maximized is given by:

$$
L(y(X, \beta))=\sum_{i=1}^{n}\left(y_{i} \cdot \ln F_{i}+\left(1-y_{i}\right) \cdot \ln \left(1-F_{i}\right)\right)
$$

where $\mathrm{yi}=\mathrm{Xi} \mathrm{b}$ is the realization of the binary dependent variable. In our case, this binary variable equals 1 when the firm is a born global and 0 when the company internationalizes gradually.

In the first logistic regression model we studied the distinction between those who generate some volume on sales, i.e. achieve success in the industry and survive, from those who do not generate an adequate volume of sales to survive. While in the second logistic regression model we assess the probability that a beneficiary of CORFO's CSP becomes a high growth entrepreneur according to the influence of a number of variables including the advice of an incubator. A summary of the key variables is presented in Table 1. 
Table 1.

Key Variables

\begin{tabular}{|c|c|c|}
\hline Variable & Type & Description \\
\hline Success & Dummy variable takes a value of 0 for no and 1 for yes. & Has survived the organization? \\
\hline Gazelle & Dummy variable takes a value of 0 for no and 1 for yes & $\begin{array}{l}\text { Is the organization a dynamic } \\
\text { entrepreneurship? }\end{array}$ \\
\hline Workers & Continuous variable ranging from 0 to 40 & Total number of workers \\
\hline Exports & Dummy variable takes a value of 0 for no and 1 for yes & Is the organization exporting? \\
\hline Sector & $\begin{array}{l}\text { Categorical variable takes value of } 1 \text { for food, } 2 \text { for biote- } \\
\text { chnology, energy, and environmental, } 3 \text { for education, } 4 \\
\text { for manufacturing, } 5 \text { for mining and infrastructure, } 6 \text { for } \\
\text { multisectorial, } 7 \text { for health, } 8 \text { for TIC, } 9 \text { for trade, and } 10 \\
\text { for tourism. }\end{array}$ & Industrial sector \\
\hline Technology & $\begin{array}{l}\text { Dummy variable takes a value of } 0 \text { for low technology } \\
\text { and } 1 \text { for high tech }\end{array}$ & Level of technology in the sector \\
\hline Gender & $\begin{array}{l}\text { Dummy variable takes a value of } 0 \text { for female and } 1 \text { for } \\
\text { male }\end{array}$ & Gender \\
\hline Education & $\begin{array}{l}\text { Categorical variable takes value of } 1 \text { for compulsory } \\
\text { education, } 2 \text { for higher education, and } 3 \text { for postgraduate } \\
\text { education }\end{array}$ & Educational level \\
\hline Work_exp & Continuous variable ranging from 0 to 44 & Years of work experience \\
\hline Entrepreneurship & Dummy variable takes a value of 0 for no and 1 for yes & Previous entrepreneurship efforts \\
\hline Region & Dummy variable takes a value of 0 for no and 1 for yes & Located in the metropolitan region \\
\hline Incubator & Dummy variable takes a value of 0 for no and 1 for yes & University incubator? \\
\hline Capital_assigned & $\begin{array}{l}\text { Continuous variable ranging from } 6,250,000 \text { to } \\
277,000,000\end{array}$ & Subsidy provided by CORFO \\
\hline
\end{tabular}

Source: Author's own.

Table 2.

Provides descriptive statistics for the variables selected from this survey.

\begin{tabular}{lccccc}
\hline Variable & Obs & Unique & Mean & Min & Max \\
\hline Success & 238 & 2 & 0.5798319 & 0 & 1 \\
Gazelle & 238 & 2 & 0.2142857 & 0 & 1 \\
Workers & 236 & 27 & 5.144 .068 & 0 & 40 \\
Exports & 238 & 2 & 0.1260504 & 0 & 1 \\
Sector & 238 & 9 & 5.731 .092 & 1 & 10 \\
Technology & 238 & 2 & 0.2605042 & 0 & 1 \\
Gender & 238 & 2 & 0.894958 & 0 & 1 \\
Education & 237 & 3 & 1.932 .489 & 1 & 3 \\
Work_Exp & 225 & 32 & 1.113 .778 & 0 & 44 \\
Entrepreneship & 238 & 2 & 0.3739496 & 0 & 1 \\
Region & 238 & 2 & 0.5420168 & 0 & 1 \\
Incubator & 238 & 2 & 0.3529412 & 0 & 1 \\
Capital_Assigned & 233 & 222 & $6.67 \mathrm{e}+07$ & 6250000 & $2.77 \mathrm{e}+08$ \\
\hline
\end{tabular}

Source: Author's own.

\section{First logistic model}

The first logistic regression model describes the beneficiaries who were successful in their business from those who were not. The success is measured through the level of sales and if they were able to survive. Therefore, the dependent variable for the model is a binary variable for sales $(0=$ no success (do not show permanent sales), and $1=$ success (with permanent sales)).

In this first model the independent variables are: Sector (it is a categorical variable that takes value of 1 for food, 2 for biotechnology, energy, and environmental, 3 for education, 4 
for manufacturing, 5 for mining and infrastructure, 6 for multisectorial, 7 for health, 8 for TIC, 9 for trade, and 10 for tourism), Techonology (it is a dummy variable that takes a value of 0 for low technology business and 1 for high tech), Gender (it is a dummy variable that takes a value of 0 for female and 1 for male), Education (it is a categorical variable that takes value of 1 for compulsory education, 2 for higher education, and 3 for postgraduate education), Work $\exp$ (it is a continuous variable ranging from 0 to 44 , according to the years of experience), Entrepreneurship (it is a dummy variable that takes a value of 1 if the entrepreneur has developed previous entrepreneurships, and 0 otherwise), Region (Dummy variable takes a value of 1 if the firm office is located in metropolitan region, Santiago, and 0 other region), Incubator (dummy variable that takes a value of 1 if the beneficiary is supported by University incubator, and 0 otherwise), and Capital_assigned (it is a continuous variable ranging from 6,250,000 to $277,000,000$ according to the subsidy provided by CORFO).

\section{Second logistic model}

The dependent variable for the second model is another binary variable named Gazelle that assess the ability of a firm to be defined as a high-growth entrepreneurship, where 0 indicates non a high-growth entrepreneurship, and 1 represents a high-growth entrepreneurship.

The independent variables for this second model are: Workers (it is a continuous variable ranging from 0 to 40 according to the total number of workers), Sector (it is a categorical variable that takes value of 1 for food, 2 for biotechnology, energy, and environmental, 3 for education, 4 for manufacturing, 5 for mining and infrastructure, 6 for multisectorial, 7 for health, 8 for TIC, 9 for trade, and 10 for tourism), Techonology (it is a dummy variable that takes a value of 0 for low technology business and 1 for high tech), Gender (it is a dummy variable that takes a value of 0 for female and 1 for male), Education (it is a categorical variable that takes value of 1 for compulsory education, 2 for higher education, and 3 for postgraduate education), Work_exp (it is a continuous variable ranging from 0 to 44, according to the years of experience), Entrepreneurship (it is a dummy variable that takes a value of 1 if the entrepreneur has developed previous entrepreneurships, and 0 otherwise), Region (Dummy variable takes a value of 1 if the firm office is located in metropolitan region, Santiago, and 0 other region), and Incubator (dummy variable that takes a value of 1 if the beneficiary is supported by University incubator, and 0 otherwise)

\section{Results}

To assess the factors that are playing an important role in explaining the success of a firm financed by the SCP Line 1 and Line 2 a logistic regression model was estimated. The results are presented in Table 3. 
Table 3.

First Logistic Regression Model

\begin{tabular}{|c|c|c|c|c|}
\hline Model: & Coeff. Est. & $95 \% \mathrm{CI}$ & $\mathrm{z}$ & P-value \\
\hline \multicolumn{5}{|l|}{ Success } \\
\hline \multicolumn{5}{|l|}{ Sector $($ base 1 = food) } \\
\hline $2=$ biotechnology, energy, environmental & -13.092 & $(-1525.75,1499.56)$ & -0.02 & 0.986 \\
\hline $3=$ education & -0.009 & $(-2.69,2.67)$ & -0.01 & 0.994 \\
\hline $4=$ manufacturing & 0.460 & $(-0.90,1.82)$ & 0.66 & 0.508 \\
\hline $6=$ multisectorial & -0.686 & $(-1.78,0.41)$ & -1.22 & 0.222 \\
\hline $7=$ health & -1.565 & $(-3.68,0.55)$ & -1.44 & 0.148 \\
\hline $8=\mathrm{TIC}$ & -13.869 & $(-1526.52,1498.78)$ & -0.02 & 0.986 \\
\hline $9=$ trade & -0.494 & $(-2.31,1.32)$ & -0.53 & 0.594 \\
\hline $10=$ tourism & -2.111 & $(-3.52,-0.69)$ & -2.92 & $0.004 * * *$ \\
\hline Techonology $(0=$ low tech, $1=$ high tech $)$ & 13.405 & $(-1499.25,1526.06)$ & 0.02 & 0.986 \\
\hline Gender $(0=$ female, $1=$ male $)$ & -0.008 & $(-1.03,1.01)$ & -0.02 & 0.987 \\
\hline \multicolumn{5}{|l|}{ Education (base $1=$ compulsory education) } \\
\hline $2=$ higher & 0.671 & $(-.264,1.60)$ & 1.41 & 0.160 \\
\hline $3=$ postgraduate & -0.586 & $(-1.97,0.79)$ & -0.83 & 0.407 \\
\hline Work_exp & 0.036 & $(-0.01,0.08)$ & 1.44 & 0.149 \\
\hline Entrepreneurship $(0=$ no, $1=$ yes $)$ & 2.612 & $(1.65,3.56)$ & 5.37 & $0.000^{* * *}$ \\
\hline Region $(0=$ no, $1=$ yes $)$ & 0.149 & $(-0.61,0.91)$ & 0.38 & 0.701 \\
\hline Incubator $(0=$ no, $1=$ yes $)$ & -0.408 & $(-1.18,0.37)$ & -1.03 & 0.305 \\
\hline Capital_assigned & 0.000 & $(2.7 \mathrm{e}-10,2.6 \mathrm{e}-08)$ & 2.00 & $0.045^{* *}$ \\
\hline Constant & -1.381 & $(-3.13,0.36)$ & -1.55 & 0.122 \\
\hline Pseudo R2 & 0.305 & & & \\
\hline Observations & 220 & & & \\
\hline
\end{tabular}

Z-score indicates significance level as follows: $* * * \mathrm{p} \leq 0.01, * * 0.01<\mathrm{p} \leq 0.05, * 0.05<\mathrm{p} \leq 0.10$

In the logistic regression model presented in Table 3, there are three variables that were statistically significant: the touristic sector, entrepreneurship, and the capital assigned. The results suggest that being in the touristic sector is negatively associated with the probability of being successful in the business. On the other hand, having previous entrepreneurship efforts increases the probability of success with their new business, and increases in the capital assigned also increases the probability of success. According to Table 3, the incubator variable was not statistically significant, indicating that there is not a difference in the success of an entrepreneur if receives advice from a NUI or an UI. Thus, we reject the first hypothesis that an UI may influence more in a project financed by the SCP.

Importantly, the results of this first model show that having experience in previous startups, and be able to raise capital through other funding sources, such as banks, private investors, among others, may be an important variable to increase the likelihood of having a successful business. The negative effect of the variable measuring the touristic Sector is interesting. The involvement of projects funded by CORFO's SCP in this sector decreases the probability of generating sustainable sales over time to succeed and stay in business.

Table 4 presents the results of the second logistic regression model that assess the probability of being a high-growth entrepreneur. 
Table 4.

Second Logistic Regression Model

\begin{tabular}{|c|c|c|c|c|}
\hline Model: & Coeff. Est. & $95 \% \mathrm{CI}$ & $\mathrm{Z}$ & P-value \\
\hline \multicolumn{5}{|l|}{ Gazelle } \\
\hline Workers & 0.150 & $(0.09,0.20)$ & 5.22 & $0.000 * * *$ \\
\hline Exports & 1.190 & $(0.04,2.33)$ & 2.03 & $0.042 * *$ \\
\hline \multicolumn{5}{|l|}{ Sector $($ base $1=$ food $)$} \\
\hline 2 = biotechnology, energy, environmental & -11.342 & $(-2509.88,2487.20)$ & -0.01 & 0.993 \\
\hline $3=$ education & 2.266 & $(-1.97,6.50)$ & 1.05 & 0.295 \\
\hline $4=$ manufacturing & -0.568 & $(-2.43,1.30)$ & -0.60 & 0.551 \\
\hline $6=$ multisectorial & 0.044 & $(-1.32,1.41)$ & 0.06 & 0.949 \\
\hline $7=$ health & -1.555 & $(-4.72,1.61)$ & -0.96 & 0.337 \\
\hline $8=\mathrm{TIC}$ & -10.139 & $(-2508.68,2488.40)$ & -0.01 & 0.994 \\
\hline $9=$ trade & -2.103 & $(-5.00,0.79)$ & -1.42 & 0.155 \\
\hline $10=$ tourism & -1.078 & $(-3.50,1.34)$ & -0.87 & 0.383 \\
\hline Techonology $(0=$ low tech, $1=$ high tech $)$ & 10.893 & $(-2487.65,2509.43)$ & 0.01 & 0.993 \\
\hline Gender $(0=$ female, $1=$ male $)$ & -1.672 & $(-3.11,-0.23)$ & -2.28 & $0.023 * *$ \\
\hline \multicolumn{5}{|l|}{ Education (base $1=$ compulsory education) } \\
\hline $2=$ higher & -0.735 & $(-2.36,0.89)$ & -0.89 & 0.376 \\
\hline $3=$ postgraduate & -0.818 & $(-2.84,1.20)$ & -0.79 & 0.428 \\
\hline Work_exp & 0.030 & $(-0.01,0.07)$ & 1.29 & 0.196 \\
\hline Entrepreneurship $(0=$ no, $1=$ yes $)$ & 1.466 & $(0.42,2.50)$ & 2.76 & $0.006 * * *$ \\
\hline $\operatorname{Region}(0=$ no, $1=$ yes $)$ & 0.237 & $(-0.66,1.13)$ & 0.52 & 0.606 \\
\hline Incubator $(0=$ no, $1=$ yes $)$ & 1.125 & $(0.23,2.01)$ & 2.47 & $0.013 * *$ \\
\hline Constant & -2.114 & $(-4.29,0.07)$ & -1.90 & 0.058 \\
\hline Pseudo R2 & 0.402 & & & \\
\hline Observations & 220 & & & \\
\hline
\end{tabular}

Z-score indicates significance level as follows: $* * * \mathrm{p} \leq 0.01, * * 0.01<\mathrm{p} \leq 0.05, * 0.05<\mathrm{p} \leq 0.10$

The results in Table 4 shown that there are five variables that were statistically significant: number of workers, exports level, gender, having previous entrepreneurship and type of incubator. The results from the logistic model suggest that increases in the number of workers increases the probability of having a high-growth entrepreneurship. At the same time, if the organization is exporting increases the probability of having a high-growth entrepreneur. Contrary, being a male decreases the probability of a high-growth entrepreneurship but having a previous start-up increases the probability of being a high-growth entrepreneur. Finally, the positive effect of being an UI implies a higher probability that an entrepreneur, transforms his/ her business into a high-growth entrepreneurship.

In this second model we see a positive and statistically significant influence regarding the participation of an UI supporting businesses in order to become high-growth entrepreneurships. Therefore, there is no evidence to reject the second hypothesis about the benefits of having participation of UI in CORFO's SCP to increase the probability of the emergence of highgrowth entrepreneurships, instead of NUI.

\section{Discussion of results and limitations}

The size reached by projects financed by CORFO's SCP, through UI is much higher than the size of projects supported by NUI. This outcome allows us to infer that many NUI are focused on small projects which, in the data, do not exhibit a potential of scalability consistent 
with growth rates for high-growth firms, therefore, in the attribute "scalability of projects", UI show a better performance than NUI.

It seems that the support and selection of institutions related to universities, which are bigger, more complex and prestigious than NUI, have a major capacity to attract high impact projects. This is probably linked to the reputation and visibility of these organizations, which gives greater public recognition and exposure, counting on a higher budget for advertising, more networks and better access to relevant experiences than a NUI. Also it can be argued that UI play a more social role than their private peers, supporting innovative projects with a high impact potential, due to their obligation to comply with an institutional mission for the creation of knowledge, and not only generate actions to develop good business, but particularly those able to generate a greater impact on our society.

From the agency theory point of view, and regarding the initial discussion of our work, we can analyse that the choice of beneficiaries from UI is more aligned with the objectives which CORFO's SPC seeks, than the choices its peers make, NUI, about the beneficiaries who apply to the program. Maybe, the fact that the incubators receive fixed payment, in any case, by the beneficiaries that are accepted by CORFO's SCP activates a control problem, where certain incubators could develop opportunistic behaviour, trying to maximize the number of projects they support, instead of efficiently strengthening the entrepreneurs who seek growth opportunities.

Changing the type of contract with the incubators, for instance, not making a fixed payment for each entrepreneur benefited by the program, but instead paying incubators according to the results they obtain (for example. according to the sales volume, personnel hired or capital raised), would allow supporting the alignment and congruence of the incubator objectives with the CORFO program mission and objective.

Why is it difficult to align CORFO and the incubators' interests with a fixed payment model? The conflict of interest between the principal-agent and the agent is clear in this case. In the case of the UI, the results of this study would show that their objectives are more aligned with CORFO's SCP. The above, most likely given by the higher reputational cost that UI have of being discovered maximizing their interests over the principal (considering the university brand). While the current approach of contracts between CORFO and its incubators is not adjusted or modified, the major reputational control put on incubators could strengthen the biggest congruence of objectives with CORFO, undermining the minor alignment of private incubators. In this logic, we identified the positive relation produced when University, Government and Entrepreneurs collaborate to obtain relevant outcomes by developing and promoting the birth and development of dynamic enterprises, with high impact and growth, which can be the path to maximize the economic growth and welfare in an economy. It is particularly important to highlight that public programs for productive support -which not only give economic resources to entrepreneurs, but also technical and administrative support- could work much better if universities were also considered in the model, particularly like centers for the creation and dissemination of knowledge and good practices. The above mentioned is another example of the positive effects of the triple helix model supporting the productive forces in each country. 


\section{Conclusions}

The objective of this paper was to explore the results from public support to privates through CORFO's SCP in Chile, comparing the results of new businesses advised by UI versus NUI. The central hypothesis of this study examines whether the CORFO's SCP has better results to follow a scheme private entrepreneurs, public agencies and university incubators versus one that does not include universities. The results of the study provide valuable information so that policy makers can increase the number of programs that consider the participation of universities, complementing entrepreneurs' knowledge and experience, towards the development of a greater number of high-growth entrepreneurships in each economy. Through these results, public support could be more effective and less faced with poor results, where entrepreneurships with incremental innovations are mainly supported, that is, with a low impact, compared with radical innovations, which could show greater growth potential. Universities, in this sense, could be generating a better selection process, or at least a more critical one, by not withstanding any kind of project, except those with a greater growth potential. In the context of our work, when the government provides economic resources to private incubators, through CORFO's SCP, the results in terms of sales volume are much better, if those who select the projects to be presented to CORFO are UI instead of NUI, and thus, it is possible to define an example of value to the triple helix model, particularly in the context of developing countries. A second option for CORFO would be to change the type of contracts it has with incubators, making a lower monthly payment for each beneficiary of the program, plus a variable payment according to results that the new supported businesses obtain. This would also be a way of supporting the alignment and congruence of the incubator objectives according to CORFO's program mission and objective.

\section{References}

Almeida M. (2008). Innovation and entrepreneurship in Brazilian universities. International Journal of Technology Management and Sustainable Development, 7(1), 39-58. https://doi.org/10.1386/ijtm.7.1.39_1

Alvarez, R. \&Crespi, G. (2000). Exporter Performance and Promotion Instruments: Chilean Empirical Evidence. Estudios de Economía, 27(2), 225-241.

Audretsch, D. (2012). Determinants of High-Growth Entrepreneurship. OECD International Workshop on Highgrowth firms: local policies and local determinants, Copenhagen.

Benavente, J.M. and G. Crespi. (2003). The Impact of an Associative Strategy (the PROFO Program) on Small and Medium Enterprises in Chile. SEWPS Paper 88, June.

Bernasconi, A. (2005). University entrepreneurship in a developing country: The case of the P. Universidad Católica de Chile, 1985-2000. Springer, Higher Education 50: 247-274. https://doi.org/10.1007/s10734-004-6353-1

Bonilla, C. \& Cancino C. (2011). The Impact of the Seed Capital Program of SERCOTEC in Chile. Inter-American Developing Bank, working paper series n ${ }^{\circ}$ IDB-WP-279.

Cancino, C. (2014). Rapid internationalization of SMEs: Evidence from born global firms in Chile. INNOVAR, 24, Edición Especial 2014, 141- 151. https://doi.org/10.15446/innovar.v24n1spe.47614

Cancino, C. \& Coronado, F. (2014). Exploring the determinants of born-global firms in Chile. Academia Revista Latinoamericana de Administración, 27(3), 386-401. https://doi.org/10.1108/arla-10-2013-0154

Cancino, C., Bonilla, C. \& Vergara, M. (2015). The impact of government support programs for the development of businesses in Chile. Management Decision, 53(8), 1736-1754. https://doi.org/10.1108/md-06-2014-0428 
Cancino, C., La Paz, A.I., Ramaprasad, A. \& Thant, S. (2018). Technological Innovation for Sustainable Growth: An ontological perspective. Journal of Cleaner Production, 179, april, 31-41. https://doi.org/10.1016/j.jclepro.2018.01.059

Cancino, C., Merigó, J.M. \& Coronado, F. (2017a). A Bibliometric Analysis of Leading Universities in Innovation Research. Journal of Innovation \& Knowledge, 2(3), 106-124. https://doi.org/10.1016/j.jik.2017.03.006

Cancino, C., Merigó, J.M. \& Coronado, F. (2017b). Big names in innovation research: A bibliometric overview. Current Science, 13(8), 1507-1518. https://doi.org/10.18520/cs/v113/i08/1507-1518

Charles D. (2003). Universities and Territorial Development: Reshaping the Regional Role of UK Universities. Local Economy, 18(1), 7-20. https://doi.org/10.1080/0269094032000073780

Collewaert, V., Manigart, S. \&Aernoudt, R. (2010). Assessment of Government Funding of Business Angel Networks in Flanders. Regional Studies, 44(1), 119-130. https://doi.org/10.1080/00343400802070860

Cumming D. (2007). Government policy towards entrepreneurial finance: Innovation investment funds. Journal of Business Venturing, 22, 193-235. https://doi.org/10.1016/j.jbusvent.2005.12.002

Davidson, R. \& Mackinon, J. (1992). Regression-based methods for using control variates in Monte Carlo experiments. Journal of Econometrics, 54, 203-222. https://doi.org/10.1016/0304-4076(92)90106-2

Díaz de León, D. \& Cancino, C. (2014). De Emprendimientos por Necesidad a Emprendimientos por Oportunidad: Casos Rurales Exitosos. Multidisciplinary Business Review, 7(1), 48-56.

Etzkowitz H. \& Ranga M. (2010). A Triple Helix System for Knowledge-based Regional Development: From Spheres to Spaces. VIII Triple Helix Conference, Madrid.

Etzkowitz H., Mello J.M. \& Almeida M. (2005). Towards "meta-innovation" in Brazil: The evolution of the incubator and the emergence of triple helix. Research Policy, 34, 411-424. https://doi.org/10.1016/j.respol.2005.01.011

Etzkowitz, H. (2007). University-Industry-Government: The Triple Helix Model of Innovation. EOQ Congresses Proceedings, 51st European Organization for Quality Congress,Prague, Czech Republic.

Fairchild, R. (2011). An Entrepreneur's Choice of Venture Capitalist or Angelfinancing: A Behavioral Game-theoretic Approach. Journal of Business Venturing, 26 (3), 259-374. https://doi.org/10.1016/j.jbusvent.2009.09.003

Guerrero M., Urbano D., Cunningham J. \& Organ D. (2014). Entrepreneurial universities in two European regions: a comparison. Journal of Technology Transfer, 39 (3), 415-434. https://doi.org/10.1007/s10961-012-9287-2

Jensen, M. \& Meckling, W.H. (1976). Theory of the Firm: Managerial Behavior, Agency Costs, and Ownership Structure. Journal of Financial Economics, 3(4), 305-360. https://doi.org/10.2139/ssrn.94043

Kantis, H. \& Díaz. S. (2008). Innovación y emprendimiento en Chile: una radiografía de los emprendedores dinámicos. Documento de Trabajo Endeavor. Santiago.

Norrman, C. \& Bager-Sjögren, L. (2010). Entrepreneurship policy to support new innovative ventures: Is it effective? International Small Business Journal, 28(6), 602-619. https://doi.org/10.1177/0266242610369874

Ranga M. \& Etzkowitz H. (2013). Triple Helix systems: an analytical framework for innovation policy and practice in the Knowledge Society. Industry \& Higher Education, 27(3), 237-262. https://doi.org/10.5367/ihe.2013.0165

Rodrigues C. \& Melo A. (2012). The Triple Helix Model as an Instrument of Local Response to the Economic Crisis. European Planning Studies, 20(9), 1483-1496. https://doi.org/10.1080/09654313.2012.709063

Román, J., Cancino, C. \& Gallizo, J.L. (2017). Exploring features and opportunities of rapid-growth wine firms in Chile. Estudios Gerenciales, 33 (143), 115-123. https://doi.org/10.1016/j.estger.2017.02.004

Saad M. \& Zawdie G. (2011). Introduction to special issue: The emerging role of universities in socio-economic development through knowledge networking. Science and Public Policy, 38(1), 3-6. https://doi.org/10.3152/03023 $4211 \times 12960315267453$

Tan, H. \& Lopez-Acevedo, G. (2005). Evaluating Training Programs for Small and Medium Enterprises: Lessons from Mexico. World Bank Policy Research Working Paper 3760, Washington DC: World Bank.

Tiffin S. \& Kunc M. (2011). Measuring the roles universities play in regional innovation systems: a comparative study between Chilean and Canadian natural resource-based regions. Science and Public Policy, 38(1), 55-66. https:// doi.org/10.3152/016502611x12849792159317 